\title{
Perceived Effects of Poverty on Urban Socio-Economic Development in Ambo Town, Ethiopia
}

\author{
Yikeber Yimesgen ${ }^{1}$, Taye Daba ${ }^{2}$ \\ ${ }^{1}$ Department of Civics and Ethical Studies, College of Social Sciences and Humanities, Ambo University, Ambo, Ethiopia \\ ${ }^{2}$ Agricultural and Rural Development Office, Ambo District Administration, Ambo, Ethiopia \\ Email address: \\ yikeberyimesgen7@gmail.com (Y. Yimesgen), tayedaba41@gmail.com (T. Daba) \\ To cite this article: \\ Yikeber Yimesgen, Taye Daba. Perceived Effects of Poverty on Urban Socio-Economic Development in Ambo Town, Ethiopia. American \\ Journal of Theoretical and Applied Business. Vol. 5, No. 4, 2019, pp. 97-101. doi: 10.11648/j.ajtab.20190504.13
}

Received: August 31, 2019; Accepted: October 7, 2019; Published: October 21, 2019

\begin{abstract}
This study was an assessment of the perceived effects of poverty on urban socio economic development in Ambo town. Poverty is deprivation in wellbeing and lack of basic necessities to sustain life. Prior researches conducted on the perception of people on the effects of poverty towards urban socio-economic development were insufficient in Ethiopia. Thus, the objectives of the study were to assess the effects of poverty on urban economic, education and healthcare development, and to examine the effects of poverty on women economic development in Ambo town. The research was a qualitative research, used primary data collected through key informant interview selected purposively from experienced persons residing in Ambo town. The data was analyzed using thematic method of analysis. The study indicated that poverty is highly prevalent in Ambo town mainly due to poor governance, corruption, poor investment flow, lack of political will from the government and political instability. The education and health care infrastructures were expanding in the town in the last decade but there were limitations in quality and service provision. Poverty has negatively affected poor people livelihoods in income generation, and medical as well as educational services in Ambo town. Women poverty in Ambo is higher than men and a significant number of women were living in destitution. Many women in Ambo town were economically dependent on men.
\end{abstract}

Keywords: Ambo, Urban Poverty, Urban Development, Women Development

\section{Introduction}

Poverty can be defined as lack of basic necessities of human beings such as food and water, shelter, education, medical care and security. Poverty is deprivation and dispossession of wellbeing [1]. Poverty is multi-dimensional issue and it is a major socio-economic problem of people living in the developing countries [2]. Poverty is highly prevalent in developing countries especially in the sub Saharan Africa [3]. Ethiopia is one of the sub Saharan Countries in which poverty was highly prevalent. Many Ethiopians in the urban areas are also living in poverty. Ethiopia is one of the world's poorest countries and faced dire challenges for alleviating poverty in the past decades [4]. Poverty is a main challenge for Ethiopia and about 22 million people are living below the poverty line even though the poverty rate is declining. Ethiopia's human development index in the year 2015 was 0.448 which puts it in the low human development category and ranked $174^{\text {th }}$ position out of 188 countries [5].

Various studies have been conducted on the prevalence of poverty and food insecurity in Ethiopia. A study by Kedir \& Mckay about urban poverty in Ethiopia by focusing on the incidence of poverty and associated factors found that there is high level of chronic poverty in the urban areas especially in the northern and central cities of Ethiopia [6]. But their study was based on quantitative methods and did not study people's perception towards the effects of poverty on urban development qualitatively. Another study on urban poverty, based on a data from the Ethiopian Urban Household survey, indicated that the incidence of urban poverty in Ethiopia is high with a head count index of more than $40 \%$, but it did not show people's perception towards urban poverty [7].

Other research studies were also conducted on the role of economic growth for reducing urban poverty. For example, a study by the Department of International Development stated that a rapid growth is the main means for poverty reduction; 
and growth and poverty reduction has a positive relationship [8]. The relation between poverty and development was highlighted by various scholars since poverty has impacts on economic development. Poverty can be a cause for poor development and on the other hand low level of development substantiates poverty; reducing poverty and promoting growth are not conflicting objectives [3]. However there are distinct views on this issue and some academics claim that the efforts for poverty reduction may minimize the expenditures required for accelerated growth. While others argue that if many people are not benefited from growth and are living in poverty it will result in impatience and rejection of growth by the masses [3]. Therefore, it is important to know how poverty and urban development are interlinked and perceived by people in Ethiopia.

It is believed that women are among the most affected segments of population in poverty. In a study conducted by Jayamohan \& Kitesa regarding the relationship between poverty and gender in Ethiopia indicates that the severity of poverty is more common among female headed households than male headed households though the level of poverty shows improvement among female headed households more than male headed households [9]. The effects of poverty on women socio economic development in urban areas was also not well researched especially in Ethiopia. Thus, the study also emphasized on how poverty affects women socio economic development in Ambo town. Therefore this research was made to fill these knowledge and empirical gaps. Hence it emphasized at assessing the perceived impacts of poverty on the economic and social development of Ambo town.

The researchers believed that the research may be helpful to know the urban poverty status in Ambo town, and how poverty affects the economic and social developments in Ambo town as well as to know the effects of poverty on women socio economic development in Ambo town.

\subsection{Objectives}

The general objective of the study was to assess the perceived effects of poverty on urban socio-economic development in the study area.

Specific Objectives of the study were:

(a) To assess the perceived effects of poverty on urban economic development in the study area.

(b) To analyze the effects of poverty on education, healthcare and urban infrastructure development in the study area.

(c) To examine the perceived effects of poverty on women socio - economic development in the study area.

\subsection{The Research Questions}

(a) What are the effects of poverty on urban economic development in the study area?

(b) What are the effects of poverty on urban education, healthcare and urban infrastructure development in the study area?

(c) What are the perceived effects of poverty on women socio economic development in the study area?

\section{Research Methods}

\subsection{Description of the Study Area}

The research was conducted in Ambo town. Ambo town is located in west Shewa Zone of the Oromia national Regional State in central Ethiopia; and it is the capital town of West Shewa Zone. Relatively Ambo town is located 114 KM West of Addis Ababa city, in the Addis Ababa - Wollega highway.

Based on the report from Ambo town Mayor Office, Ambo town has 67,514 people in 2017 . The 2007 population and housing census by Central Statistical Agency (CSA) of Ethiopia reported that the total population of Ambo town was 50,267 individuals. The number of Households in 2017 was 15,223 and the average family size of the town was 3.8 individuals [10].

\subsection{Methods of Data Collection}

The data collection method for the study was through key informant interview and focus group discussions. The key informant interview and focus group discussion participants were selected purposively. The participants were selected with due consideration of their period of residence in Ambo town and their level of poverty. The researchers selected the participants from among poor people living in the town to get sufficient data on the study issue. Interviewees selected for the study have resided in the town for more than 20 years. For the interview 12 individuals have participated based on a saturation point. From these, nine of the interviewees were male and three were females. Key informant interview was conducted to get pertinent information on the study issue. Key informant interview is an important method of data collection for obtaining the attitudes, perceptions and personal information of the people [11]. The key informant interview was done using a checklist by the researchers themselves. Three focus group discussions were conducted for this study. The participants in the FGDs were mainly poor women residing in the town for many years. Focus group discussants were selected purposively from women who are poor and have sufficient knowhow on the poverty and development issues and problems of Ambo town.

\subsection{Research Design}

The research approach was a qualitative research approach. It mainly focused on describing the perceived effects of poverty in urban economic and social development as well as women development in Ambo town. The research was a descriptive type of research which describes the prevalence of poverty in Ambo town, how it affects the economic, social development and the effects of poverty on women development by using qualitative data. Secondary sources from the reports of Ambo local government were also taken for the study. 
For the study a thematic analysis method was employed for analyzing the primary data. Thematic analysis is the process of identifying patterns or themes within qualitative data and it use these themes to address the research or say something about an issue [12]. The method of analysis for this study was selected with due consideration of the objectives and research questions of the research.

\section{Result and Discussion}

The study found that poverty is highly prevalent in Ambo and it is a primary problem for most people in the town. In comparison with other towns of Ethiopia, poverty in Ambo is higher due to the lower attention and poor policies of the governments for urban development. Most of the people in Ambo are poor. Poverty prevalence is not uniform in the town; the poverty situation is higher among women and people living with disability than men and physically able people. For instance an interviewee said that $\mathrm{d} u e$ to the physical disability they could not work efficiently; the government did not provide job opportunities for people living with physical disabilities. The results indicated that there is a high prevalence of poverty in the town but the most affected groups by poverty were women and the disadvantaged groups especially disable people.

In terms of age, youth groups were affected by poverty. Many youth and women in Ambo town did not have a means for generating income and there is limited (no) employment opportunity for the youth. Poverty limits the opportunities of youth in Ambo in getting initial capital for business development. Many poor people did not have initial capital that can be used for growing themselves. Besides, the micro financial institutions in Ethiopia require difficult collateral requirements [13]. But the youth and women in Ambo town do not have sufficient collateral to borrow from the micro financial institutions and banks. Many people in Ambo did not have income needed to grow and to come out of poverty as a result they lead subsistence life and a substantial number of youth are migrating to other places. A participant said that due to poverty we were not able to generate income for our household in Ambo and my wife went to the Middle East to work as a maid so that we may have capital. similar to this findings, a study conducted on the determinants of urban poverty in Southern Nations nationalities region of Ethiopia found that savings and credit utilization from micro financial institutions were determinant factors for urban poverty and households with practice of saving and credit utilization have better chance to escape from poverty because they have good ground to invest on profitable businesses and coping short term market shocks [14].

The poverty situation in the town is exasperated by high inflation. The participants assume that the inflation is rising beyond the capacity of the people. Many people are unable to fulfill basic needs; especially having a house is much difficult for the poor in Ambo. As one participant said "people are starving and many of them are not covering for their daily food consumption. Especially food price in the town is too high and the poor are unable to properly feed themselves with such high price". Another participant said that the price of goods is hiking every time but our income is too small to buy food and to send our children to school.

This indicates that poverty in Ambo has a strong impact on food security and many poor people are food insecure not because of unavailability of food but they are unable to access food (unable to afford for the food prices) due to high inflation. Relating to this, a study on urban poverty in Addis Ababa city indicated that high food inflation resulted in higher food insecurity and poverty [15].

Participants identified various factors for the urban poverty in Ambo town. Among the factors includes: little attention given from the government to the towns development, corruption, incompetence of the government officials and low level of investment. The administrators of the town employ incompetent civil servants based on corruption, and this contributes for inefficiency in the local administration that further deteriorates the poverty situation of the town.

The participants stress that the administrators of Ambo are responsible for the deteriorating poverty situation in Ambo town. The participants stated that poverty in Ambo prevails due leadership problem or bad governance and corruption. Besides, the town administration was not willing to engage with the community for the town's development. Participants stress that government officials appointed at Ambo town administration were incompetent to solve the poverty situation of the town and they are corrupted. Due to corruption many investors have left the town. Contrasting to this finding, a report by Minstry of Urban Development Housing and Construction indicate that the Federal Democratic Republic of Ethiopia (FDRE) government has made efforts to create conducive environment for the industrial development to attract both domestic and foreign investment [16]. The FDRE investment proclamation and other laws also provide enabling environment for investments of the private sector in Ethiopia [17].

Low level of investment flow to the town was also attributed to the political instability in the area and limited knowledge for the business opportunities of Ambo town. In Addition to this, the administrators did not attract and encourage investors to invest in the town. There is also a cumbersome bureaucracy, corruption, and limitations in fulfilling necessary conditions for investment such as land, electricity and finance.

Regarding the effects of poverty on education, healthcare, potable water, electric infrastructure development in Ambo town, the participants identified various problems. In terms of education; various schools were opened in the town but there is poor service quality in the educational institutions. The school infrastructure is expanded at various areas of the town but the classrooms are not inclusive for people living with disability. Poor teachers' performance in the education is among the problems of education. Due to poor quality in public schools, people send their children to better private 
schools. But children of the poor lack the opportunity to learn in better private schools.

Participants perceive that there is improvement in potable water provision in the town. However in the summer season due to silt filling at Huluqa micro dam, which is the source of potable water for the area, there is frequent water shortage in the town. The electricity service in Ambo town was found poor. Besides, people perceive that the price for electricity service provision was high.

The road construction growth in the town was stagnant. The roads constructions were not completed on the planned time. For example the Ambo - Woliso highway was not completed on the planned time. To resolve this problem the local people have participated to build roads.

Regarding the Health care services development in the town participants said that there are hospitals and clinics (public and private) but they are not properly serving the community. There is shortage of medical equipment, supplies, pharmaceuticals; and poor service delivery was a common problem in health institutions. A participant said that "by going to public hospitals you will add another infection; when we go to the hospital we did not get proper medical treatment and cure instead we receive other disease". The health center and hospitals are not filled with qualified professionals that provide better healthcare services. Adding to the poor health services, the town administration did not control the liquid waste disposals and some hotels dispose liquid waste including toilet to the ditches of the main road and this created another public health problem.

The government owned hospitals and healthcare centers have problems in serving the poor and it is difficult to get proper medication. A participant said that when we want to use free medical service at the government hospitals, they haven't the pharmaceuticals; they send us to private pharmacy and clinics that we could not afford for high price in private health institutions. Poor people could not take medical services from private clinics and private hospitals due to low income. Many poor people are not able to afford for their health services and some of them went to religious institutions for cure because they have no money to go to hospitals.

The study indicated that women's poverty condition in Ambo town was terrible. Women poverty in the town is higher than men. Especially women who are voiceless are highly affected by poverty than active ones. Many women /housewives/ are totally dependent on the income of their husbands because they did not have their own income. Women did not get equal pay for the same work especially when they work as daily laborers in the private companies. There is no big factory that can absorb women, and only few companies are operating in the town so that many women are working in informal sectors such as selling local alcohol products (tella and katikala). However, the participants said that nowadays it is becoming difficult for women to support themselves through informal works such as preparing local alcohol /tella and Katikala/ due to high price in inputs (such as fire wood, barley, maize and sorghum). Ambo University has contributed in reducing unemployment in Ambo town to some extent by employing women and increasing market opportunities for informal operators. From this we can conclude that women were highly affected by poverty in Ambo town. Similar to this finding, a study on the connection of gender and poverty found that the gender poverty difference is significant in Addis Ababa where female household heads make the largest proportion of poor people [9]. Likewise the demographic and health survey of Ethiopia study indicated that women who own assets such as land and house in urban Ethiopia were small; about $73 \%$ of women did not have house and about $87 \%$ of women did not own a land [18].

Due to poverty many women are involving in various types of works. Participants said that there is a growing incident of prostitution in the town because of lack of employment opportunities in formal and informal organizations. Poverty brings various effects on women development in the town; it reduces their opportunities for learning; make women dependent on men economically and it is difficult for them to cover their daily expenses.

\section{Conclusion}

The results indicate that urban poverty is a growing concern for Ambo town. There is a high prevalence of poverty in Ambo town and the most affected groups by poverty were women and the disadvantageous groups especially people living with disability. Due to poverty, many poor people in Ambo are becoming food insecure because they are unable to afford for high food prices due to inflation. The study found that the prime responsibility for poverty in Ambo town goes to the government and local administrators; and poverty is highly prevalent mainly due to bad governance, corruption, poor investment flow, incompetent administration and political instability in the last decades. Thus, attractive investment environment shall be established for attracting investors that can absorb the unemployed youth. Enhancing entrepreneurship could be another solution for reducing poverty in the town.

The result indicated that education and healthcare infrastructure was built at various places in the town but with some limitations. However, public schools and healthcare centers were inefficient in their quality and service delivery. Thus, people were forced to choose private clinics, hospitals and private schools but poor people are unable to afford for the costs in the private health and education institutions. Therefore, the government must work to improve service provision in public institutions and provide opportunities for human capital development for workers of public institutions.

The result indicated that women poverty is higher than men in Ambo town. Women especially the voiceless ones were the most affected by poverty. Therefore the government shall arrange special opportunities for women economic development. The government has to organize the women, and the unemployed youth by identifying their problems; 
provide job opportunities for them. Priority should also be given for those who were not active (the voiceless). Controlling mechanisms for the budget allotted to poverty reduction in Ambo town so as to reach to the poor women shall be established.

\section{References}

[1] Sen, A. (1981). Poverty and Famines: An Essay on Entitlements and Deprivation. New York: Oxford University Press.

[2] Asselin, L. M. (2009). Analysiis of Multidimensional poverty: Theory and Case Studies. Springer.

[3] Todaro, M., \& Stephen, S. (2012). Economic Development (11 edition). Addison-Wesley.

[4] Diao, X., Gautam, M., Keough, J., Chamberlin, J., \& You, L. (2005). Growth options and poverty reduction in Ethiopia: a Spatial, Economywide Model Analysis from 2004-15 (No. 20).

[5] UNDP. (2018). Ethiopia 's Progress Towards Eradicating Poverty. Implementation of the Third United Nations Decade for the Eradication of Poverty (2018-2027). Addis Ababa Ethiopia.

[6] Kedir, A. M., \& Mckay, A. (2003). Chronic Poverty in Urban Ethiopia: Panel Data Evidence. Staying Poor: Chronic Poverty and Development Policy, (April), 7-9. Manchester.

[7] Alemayehu, T. (2006). The Analysis of Urban Poverty in Ethiopia. University of Sydney.

[8] Department of International Development. (n.d.). Growth: Building Jobs and Prosperity in Developing Countries.
[9] Jayamohan, M. K., \& Kitesa, A. T. (2014). Gender and poverty - an analysis of urban poverty in Ethiopia. Development Studies Research, 1 (1), 233-243.

[10] CSA. (2007). The 2007 population and housing census of Ethiopia: Statistical report for Amhara Region; part I: Population size and characteristics.

[11] Kothari, C. R. (2004). Research Methodology Methods and Techniques (Second Rev). New Age International Publishers

[12] Maguire, M., \& Delahunt, B. (2017). Doing a Thematic Analysis: A Practical, Step-by-Step Guide for Learning and Teaching Scholars. AISHE-J, 3 (3), 3352.

[13] Belay, K., Asmera, T., \& Tekalign, M. (2015). Factors Affecting Developments of Micro and Small Enterprises. International Journal of Scientific and Research Publications, $5(1), 1-10$.

[14] Mohammed, M. B. (2017). Measurement and Determinants of Urban Poverty in. International Journal of Scientific and Research Publications, 7 (3), 181-189.

[15] Birhane, T., Shiferaw, S., Hagos, S., \& Mohindra, K. S. (2014). Urban food insecurity in the context of high food prices: a community based cross sectional study in Addis Ababa, Ethiopia. BMC Public Health, 14, 1-8.

[16] Minstry of Urban Development Housing and Construction. (2014). National report on Housing \& Sustainable Urban Development. Addis Ababa.

[17] Fedreal Negarit Gazeta. Investment Proclamation., (2012). Retrieved https://doi.org/10.1080/21665095.2014.917053

[18] Central Statistical Agency (CSA), \& ICF. (2016). The Ethiopian Demographic and Health Survey. Addis Ababa, Ethiopia and Rockvile, Maryland, USA. 